\title{
Group Size and Protest Mobilization across Movements and Countermovements
}

\author{
ANSELM HAGER Humboldt-Universität zu Berlin, Germany \\ LUKAS HENSEL Peking University, China \\ JOHANNES HERMLE University of California, Berkeley, United States \\ CHRISTOPHER ROTH University of Cologne, Germany
}

\begin{abstract}
$M$
any social movements face fierce resistance in the form of a countermovement. Therefore, when deciding to become politically active, a movement supporter has to consider both her own movement's activity and that of the opponent. This paper studies the decision of a movement supporter to attend a protest when faced with a counterprotest. We implement two field experiments among supporters of a right- and left-leaning movement ahead of two protest-counterprotest interactions in Germany. Supporters were exposed to low or high official estimates about their own and the opposing group's turnout. We find that the size of the opposing group has no effect on supporters' protest intentions. However, as the own protest gets larger, supporters of the right-leaning movement become less while supporters of the left-leaning movement become more willing to protest. We argue that the difference is best explained by stronger social motives on the political left.
\end{abstract}

\section{INTRODUCTION}

$\mathbf{M}$ any of the pivotal social movements of the last 100 years - those fighting for racial justice, gay rights, or, on the other hand of the political spectrum, fascism-were met with fierce resistance in the form of a countermovement. For example, the women's movement, which took root in the mid-nineteenth century, was soon opposed by antifeminists who rejected calls for improving women's rights. In such a situation, the influence of a movement depends not only on the engagement of its own supporters but also on the activity of the opposing movement. The decision of a citizen to become active in her preferred movement is therefore shaped by two considerations: her influence depends on both the engagement of like-minded peers in her preferred movement and the engagement of supporters of the opposing movement. Despite the importance of such movement-countermovement dynamics, there is currently little evidence on how strategic interdependence shapes political activism within and across movements. The recent surge in protests on both sides of the

Anselm Hager (D), Assistant Professor of International Politics, Department of Social Sciences, Humboldt-Universität zu Berlin, Germany, anselm.hager@hu-berlin.de.

Lukas Hensel (D), Postdoctoral Research Fellow, Guanghua School of Management, Peking University, China, lukas.hensel@pku.edu.cn.

Johannes Hermle (D), Alumnus, University of California, Berkeley, United States, and Research Affiliate, Institute of Labor Economics, Bonn, Germany, j.hermle@berkeley.edu.

Christopher Roth (D), Professor of Economics and Management, University of Cologne, Germany, roth@wiso.uni-koeln.de.

Received: October 28, 2020; revised: April 17, 2021; accepted: August 27, 2021. First published online: December 10, 2021. political spectrum makes this a particularly pressing issue (Brannen, Haig, and Schmidt 2020).

Consider the case of a citizen who weighs whether to attend a protest organized by her preferred movement. How does turnout in the potential activist's own protest as well as in the opposing movement's protest affect her willingness to become politically active? As the own protest grows in size, instrumental models of collective action contend that free-riding incentives reduce a potential activist's likelihood of turning out (Olson 1965). By contrast, models focusing on social norms (Ostrom 2000) or reciprocity (Lubell and Scholz 2001) predict that growing turnout in her own movement's protest leads an activist to become more likely to engage. Similarly, it remains unclear how a potential activist's willingness to participate is affected by turnout at a protest of a movement they oppose. Theories of social identity imply that greater turnout in the opposing movement's protest leads the activist to invest more in her own movement (Huddy and Mason 2008). By contrast, bandwagoning models predict that potential activists shy away from political action if the opposing movement's protest grows in size (McAllister and Studlar 1991).

The theoretical ambivalence underlines the need to empirically tease apart strategic interdependence within and across political movements. While movement-countermovement dynamics have received scholarly attention (Andrews 2002; Jennings and Andersen 1996; Lohmann, 1994; Tarrow, 1996a; Vann 2018), the existing evidence is largely correlational and does not rely on individual-level data on protest behavior. Aggregated data, in particular, present a serious challenge because they do not allow the researcher to understand the decision making of individual supporters when faced with an opposing movement. This article circumvents these empirical challenges by 
presenting evidence from a field experiment to causally study, at the individual level, the qualitative nature and quantitative extent of strategic interactions between both like-minded and opposing political activists. Such a micro-level analysis is particularly valuable because it opens the possibility of studying the social and instrumental motives that underlie intended and actual protest participation.

Our evidence comes from Germany, a country emblematic of the recent rise in right-wing activism and left-leaning counteractivism in Western Europe and beyond. Germany has witnessed the rise of a number of right-wing groups, spearheaded by the Alternative für Deutschland (henceforth, AfD). The AfD frequently organizes protests to tout nationalist and xenophobic demands outside of parliament. Left-leaning organizations have formed a broad, loosely organized countermovement, which then stages counterprotests in the same location. Two such protest-counterprotest interactions took place in the cities of Berlin, in 2018, and Erfurt, in 2019, which provide the context for our study. A week ahead of the two protests, we recruited likely protesters both on the political left and right using Facebook ads. Within an online survey, we then randomly assigned respondents to receive either a high or low official expert forecast about turnout for their own protest and that of the opposing protest. We then assessed how this information affected potential activists' willingness to participate in their preferred movement's protest as well as their actual protest behavior.

We present three core findings. First, we find no evidence that potential activists react to information about the estimated turnout on the opposing side. Neither on the political left nor right does larger turnout in the counterprotest affect potential activists' protest intentions. Second, respondents do react strongly to information about estimated turnout in their own movement's protest. On the political right, potential activists are 0.15 standard deviations less likely to protest when being given information that turnout in their own group is large. Right-wing participants, therefore, decrease their willingness to protest when the own protest increases in size. Third, on the political left, we find the reverse: potential activists who are given information with high predicted turnout at their own protest have 0.17 standard deviations higher protest intentions compared with respondents who received a low turnout forecast. Thus, supporters of the left-wing movement increase their willingness to protest when their own group increases in size. Reassuringly, we confirm this finding using behavioral data on protest attendance in Berlin, where respondents were asked to send in a photo of themselves while protesting.

What are the mechanisms that give rise to the different treatment effects across the two movements? We argue that the heterogeneity across the political left and right can best be explained by differences in social motives. By social motives, we refer to three distinct phenomena: (1) commitment, (2) sociability or "relational goods" (Uhlaner 1989), and (3) social image concerns (Lacetera and Macis 2010), which operate at the micro, meso, and macro levels, respectively. At the micro level, we show that left-leaning respondents are more connected to their movement and have a stronger prior commitment to protesting. Both facts can explain why, on the left, higher predicted turnout makes a potential activist more likely to engage, thus offsetting free-riding incentives. At the meso level, we show that left-leaning protests provide significantly more enjoyment value to their supporters. As left-leaning protests grow in size, so does the enjoyment from attending the protest, thus explaining the positive treatment effect on the left. At the macro level, we use population-level data to show that left-leaning protests - which, in our context, represent the "establishment"-receive approval by the majority of society, whereas the rightleaning movement is scorned. Thus, as the left-leaning protest grows in size, so does the likelihood of receiving positive feedback, giving potential activists an additional incentive to take to the streets.

Our study adds to three core debates in the social sciences. First, we contribute to a long-standing debate on the dynamics between social movements and countermovements (Blee and Creasap 2010; Meyer and Staggenborg 1996). We add to this literature by providing causally identified, individual-level evidence regarding one important driver of movement and countermovement participation: group size. ${ }^{1}$ When focusing on movement-countermovement interactions, our evidence shows that potential activists do not take turnout levels at the protest by the opposing movement into consideration when deciding whether to join a protest. The decision to become active-whether on the political right or left - is primarily driven by dynamics within supporters' own movement. This is not to say that there is no strategic interdependence between opposing movements (see, e.g., Vann 2018). However, our findings imply that turnout at the protest of the opposing movement is not the relevant margin along which potential activists decide whether to take to the streets, at least in the case of right-wing protests and counterprotests in Germany.

Second, we contribute to a debate on the causes of participation within a given movement (Amenta 2006; Han 2016; McClendon 2014; McVeigh, Cunningham, and Farrell 2014; Vüllers and Hellmeier 2021). When focusing on dynamics within movements, our evidence points to turnout levels at one's own protest as a salient driver of intended and actual engagement. Importantly, however, there are marked differences in how turnout affects protest intentions across right-wing movements and left-wing countermovements, which have heretofore gone unnoticed. On the right, greater turnout within the own protest reduces supporters' protest intentions. The reverse holds on the political left: As

\footnotetext{
${ }^{1}$ It is important to emphasize that we study social movement participation through the lens of protests and not via other channels such as legislative lobbying or the establishment of local chapters, which have also been shown to affect the influence movements have on society (Amenta et al. 2010; McVeigh, Cunningham, and Farrell 2014). It is also important to note that we study one specific setting, thus holding macro-level variables, including the political system (Amenta 2006), constant.
} 
the own group becomes larger, potential left-leaning activists become more willing to take to the streets. The observed heterogeneity by political ideology showcases that movement-countermovement dynamics are far from symmetrical, which is a common assumption in canonical models in the literature (Meyer and Staggenborg 1996).

Third, we add to a lively debate on movement types (Hutter, Grande, and Kriesi 2016; Hutter 2014; McAdam and Tarrow 2013). We argue that, in our setting, the heterogeneity in dynamics across the political left and right can be explained by differences in social motives across movements. We argue that there are three main differences between the two movements in our setting, which can account for the opposing treatment effects. First, supporters of the left-wing movement have tighter connections to the movement and greater prior commitment to protesting and thus higher incentives to become active as their own movements' protest grows in size. Second, supporters of the left-wing movement derive greater enjoyment from protests, which arguably grows in turnout. Third, in our setting, the political right resembled the challenger movement and therefore had a small support base. The left-wing movement, by contrast, represented the establishment and was supported by society at large. As the own protest grew in size, the left may thus have expected to receive praise, explaining the positive treatment effect.

\section{THEORETICAL BACKGROUND}

Social movements, writes Tarrow, consist of "collective challenges, based on common purposes and social solidarities, in sustained interaction with elites, opponents, and authorities" (2011, 4). Much has been written about the motivations of individuals to join movements (Hager and Krakowski 2021; Klandermans 1984; Polletta and Jasper 2001), the organization of movements (Davis et al. 2005; Kriesi 1996), and the broader political opportunity structure in which movements arise (Meyer 2004; Tarrow 1996b). Social movements, however, seldom arise in a vacuum. Most historic movements faced fierce opposition, often in the form of a countermovement. Despite this empirical regularity, we know surprisingly little about how such movement-countermovement dynamics affect movement participation. In particular, there is a dearth of evidence on individual-level participation in movement protests, which constitute a primary way through which movements make themselves heard.

In this paper, we study the decision of movement supporters to attend protests when faced with low or high turnout in their own as well as in the opposing movement's protest. Following Klandermans and Oegema, our empirical focus is on potential activists - that is, individuals who "take a positive stand toward a particular social movement" (1987, 519). Our outcome is both potential activists' willingness to become engaged and whether they actually protested. ${ }^{2}$ We thus study the full process from mobilization potential to actual mobilization. Differentiating between intentions and actual participation in a protest is critical, given that only a fraction of those who intend to participate actually do so. Klandermans (1997), for instance, provides a model to analyze the step from intention to participation; the author notes that to convert intentions into actual participation, potential activists have to overcome concrete barriers such as time constraints or lack of material resources. Importantly, we focus on right- and left-leaning political protests in Germany. We mention this because it undoubtedly shapes the theoretical channels we explore in the following.

How does turnout in a potential activist's own protest and in the opposing protest affect her willingness to protest as well as her actual protest behavior? In the following, we propose different potential causal channels that link protest intentions to high-compared with low-predicted turnout in a potential activist's own protest and in the opposing protest. The channels operate at the micro, meso, and macro levels, respectively, and have received widespread attention in the literature and could, plausibly, operate in our context (we explore generalizability in a dedicated section below). We begin by discussing how turnout levels in the potential activist's own protest affect her participation intentions, before turning to turnout levels in the opposing protest.

\section{High Turnout in Own Protest and Protest Intentions}

\section{Micro Level: Social Connections to the Movement}

At the individual level, canonical models of collective action stipulate that potential activists weigh their chances of determining the protest's outcome against the cost of attending (Olson 1965). Because the outcome of a protest-for example, a change in policy (Cress and Snow 2000) - is a public good, social movements are plagued by free-riding incentives. ${ }^{3}$ Following this setup, as turnout in the own movement's protest becomes larger, the potential activist's chance to affect the outcome becomes progressively smaller such that she may become unwilling to take action. Although in practice individual protest participation is unlikely to affect political outcomes, activists may still believe that they do. Relatedly, free-riding has also been linked to a psychological literature on the diffusion of responsibility, which could become more important as expected turnout increases (McAdam 1986; McAdam, Juhl, and

\footnotetext{
${ }^{2}$ We empirically assess the link from protest intentions to behavior on page 9 , showing a strong correlation.

${ }^{3}$ Beyond attempting to directly change policy, movements may also strive to reinforce cultural values. For instance, in the context of this paper, the status-quo focused left-wing movement arguably did not try to change policy but was instead focused on reinforcing democratic values; by contrast, the right-wing movement-which, in our context, is linked to a specific anti-establishment party-arguably focused on igniting political change (cp. Shadmehr 2021).
} 
Gschwend 1988; Wiltfang and McAdam 1991). ${ }^{4}$ However, rising turnout in an activist's own protest arguably also sets in motion three social mechanisms, operating at the individual level, which might offset free-riding incentives. First, growing turnout means a potential activist is more likely to know protesters and thus be invited to join (Snow, Zurcher, and Ekland-Olson 1980). Knowing more people within the movement might also generate solidarity (Fireman and Gamson 1977). Second, even without a direct invitation, as the own movement grows in size, a potential activist may feel inspired to become active (McAdam and Paulsen 1993). Third, growing turnout may lead potential activists to feel an urge to reciprocate (Lubell and Scholz 2001). ${ }^{5}$ Taken together, whether growing turnout in one's own movement fosters or hinders willingness to participate in protests depends crucially on the presence of social motives, which might, in turn, be amplified among individuals who are more committed to the movement.

\section{Meso Level: The Social Nature of Protests}

At the meso-level, protests can be conceptualized as social events whose "enjoyment value" increases or decreases in size depending on the type of protest. Protests, in other words, can be thought of as relational goods whose consumption value changes when consumed jointly (Uhlaner 1989). As Eyerman and Jamison $(1998,7)$ write "by combining culture and politics, social movements serve to reconstitute both, providing a broader political and historical context for cultural expression, and offering, in turn, the resources of culture-traditions, music, artistic expression-to the action repertoires of the political struggle" (see also, Flacks 1988). Whether growing turnout in a potential activist's own protest increases or decreases her enjoyment value depends critically on the context. The political orientation of the protest, arguably, also plays a crucial role. Modern left-wing protests, for instance, frequently involve street parties with cheerful music being played throughout the day (Hall 2011). By contrast, right-wing protests are often a platform to express anger about society at large (Chermak, Freilich, and Suttmoeller 2013) and more often involve violent elements (Della Porta 2006). More generally, music and cultural expression have been shown to serve as facilitators of collective identity, which fosters solidarity within a movement (Danaher 2010; Eyerman 2002). In so doing, culture can function as an effective lever to overcome free-rider incentives and reinforce

\footnotetext{
${ }^{4}$ To what degree free-riding incentives are at play also depends on a number of contextual variables. Free-rider problems are arguably most common in movements that garner widespread support as opposed to small fringe movements. And, whether free-riding incentives are prevalent also depends on individual-level variables. For instance, individuals with an "activist mindset" may be more inspired to protest in light of large predicted turnout.

${ }^{5}$ Feelings of duty and obligation might also counter free-riding incentives as individuals fear that, with fewer contributions, tasks might be left undone (Oliver 1984).
}

participation intentions in light of growing protest turnout. Interestingly, the effectiveness with which culture can be used to build identity arguably depends on the type of movement. If a movement is highly diverse, there is more of a need to build a collective identity using culture, compared with more homogenous movements. As such, it is not surprising that more (racially and politically) diverse movements - including the leftwing countermovement we study-would rely more extensively on culture. ${ }^{6}$

\section{Macro Level: Societal Support}

At the macro level, the reaction to turnout in a potential activist's own protest may depend on the degree to which society approves or disapproves of a movement, giving rise to immaterial benefits of participation (Snow and Soule 2010), including solidarity and moral incentives. As protests grow in size, the likelihood that society at large learns about the protest and then praises or scorns individuals for attending arguably rises. For instance, Jennings and Saunders, in a comparative study of 48 street protests across nine countries, find that "larger demonstrations tend to increase the amount of media coverage" $(2019,2300)$. Moreover, larger protests arguably also make word-ofmouth discussions of the protests more likely, particularly in the online realm (Breuer, Landman, and Farquhar 2015). If a protest is not approved of by the majority of society, this presents a social disincentive to a potential activist, which is reinforced as the protest grows in size. At the same time, society's reaction to a protest could also be positive. Growing turnout may then increase a potential activist's propensity to protest because she expects to receive societal approval. ${ }^{7}$ The strength and direction of this macro-level channel, thus, relies on important scope conditions, such as the extent and tone of media coverage and the degree to which a given movement is supported by society.

\section{High Turnout in Opposing Protest and Protest Intentions}

\section{Micro Level: Perceived Self-Efficacy}

At the individual level, standard models of political contests posit that potential activists are more likely to protest as the opposing movement becomes larger. As Coate and Conlin $(2004,1477)$ write: "the greater the turnout expected from the opposing group, the higher a group's critical value must be in order to

\footnotetext{
${ }^{6} \mathrm{We}$ note that a less pronounced collective identity is not to be confused with weaker individual ties to the movement (i.e., the micro level). That is, movement supporters may have ties to a movement, but the movement may still have a relatively weak collective identity, and vice versa.

${ }^{7}$ We must caution that protest participation does not guarantee social esteem, though there is rigorous evidence that social esteem drives political engagement (McClendon 2014). Moreover, one should note that protest intentions and behavior are, technically, determined by potential activists' perceptions of social esteem and stigma; we revisit this issue in the section on generalizability.
} 
ensure any given chance of success." The underlying logic is that, on the margin, a potential activist's effectiveness rises as the opponent becomes more active. ${ }^{8}$ However, rising turnout in the opposing protest may also set in motion two expressive channels, which dampen protest intentions. First, greater turnout in the opposing protest may lower a potential activist's perceived self-efficacy (Finkel 1985; Klandermans and van Stekelenburg 2013), which in turn can hinder activism (Hager et al. 2021a). Second and related, greater turnout in the opposing protest may create a feeling of threat to a movement supporters' group status, which has been found to lower political engagement (Huddy, Feldman, and Cassese 2007).

\section{Meso Level: Group-Level Competition}

At the meso level, an increase in turnout in the protest of the opposing movement could have both positive and negative effects on a potential activist's propensity to protest. First, rising turnout may be interpreted by potential activists as increased political group-level competition and activists have been shown to want to inflict losses on the opponent. As Chong $(2014,76)$ writes: "political activists relish the competition and conflict of the political arena." On the other hand, as the opposing protest grows, so does the likelihood for a violent standoff, thus dampening the potential activist's inclination to become active. Moreover, the value of attending a protest may decrease in opponent turnout, as people may prefer to be part of the bigger movement (a channel that is related to the aforementioned mesolevel enjoyment mechanism within the own movement). Such a bandwagon effect has i.a. been found to exist for voter turnout (e.g., Morton and Ou 2015).

\section{Macro Level: Societal Support}

At the macro level, as argued above, higher turnout of both the protest and counterprotest likely amplifies (media) attention given to the protesters. As the opposing movement grows in size, this could either dampen or reinforce a potential activist's propensity to turn out. Among supporters of movements that can expect to receive approval from society, increased turnout in the opposing protest should reinforce protest intentions. For supporters of movements that are stigmatized by society, increased turnout in the opposing protest likely decreases incentives to turn out. As before, the macrolevel mechanism hinges critically on whether the potential activist expects to receive praise or scorn from society, which is reinforced as the opposing protest becomes larger.

\footnotetext{
${ }^{8}$ Potential activists may also be driven by a desire to inflict a loss on the opponent (Glazer 2008), whereas, in the absence of strong competition, an activist may lack a suitable opponent and thus the motivation to become active.
}

\section{DESIGN}

To study how turnout in a potential activist's own protest and in the opposing movement's protest affects her protest intentions (as well as actual protest participation), we draw on individual-level experimental evidence from Germany.

\section{Germany's Right-Wing Movement and Countermovement}

Our study takes place in the context of two protests organized by the "Alternative für Deutschland ("Alternative for Germany," AfD). The AfD is a German political party that was founded in 2013. The party falls on the far-right end of the political spectrum and is widely considered to be the political vehicle for the broader right-wing populist movement which has been sweeping across Germany (and Europe more broadly). During the so-called refugee crisis of 2015, the party shifted its economic platform to a socially conservative one, challenging Germany's relatively open immigration policies. The shift saw a massive increase in support for the party, which took over $20 \%$ of the vote in regional elections in 2016. In the 2017 national election, the AfD gained $12.6 \%$ of the vote, making it the largest opposition party in the German parliament. The significance of this event cannot be overstated. As Siri notes: "The 2017 German election was a political earthquake. The election results not only caused a major upset, the quake also changed the political landscape in a visible manner. It led to the creation of a six-party system, including, for the first time in modern history, a strong right-wing party" $(2018,142)$.

To advance its political influence, the AfD organizes protests against the German government. These protests serve as focal points for Germany's broader rightwing movement, bringing together influential organizations such as the identitarians as well as PEGIDA (Berntzen and Weisskircher 2016). The success of the AfD in recent years as well as its mobilization efforts on the streets have been highly controversial. According to national polls, over $50 \%$ of Germans perceive the AfD as a threat to democracy. As a consequence, protests organized by the AfD typically attract counterprotests by left-wing parties and organizations, which seek to defend multiculturalism. Two influential protests and counterprotests took place in Berlin on May 27, 2018, and in Erfurt on May 1, 2019. Both protests generated significant attention and constitute the setting of our experiment.

Before describing our setting, we briefly want to reflect on the terms "right-" and "left-leaning." We rely on these terms chiefly because the movement and countermovement we study identify themselves as such. The right-leaning movement is spearheaded by the AfD, which identifies as "right" (Niedermayer and Hofrichter 2016). Academically speaking, the right-leaning movement we study can more accurately be described as "populist radical right." A seminal definition for this subset of movements and parties is provided by Mudde, who argues that populist radical right parties adopt "a core ideology that is a 
combination of nativism, authoritarianism, and populism" (Mudde 2007, 26). The definition is important because it underlines the seeming irrelevance of economic factors. By contrast, the left-leaning countermovement comprises organizations that broadly identify as left-leaning. This includes the main supporting political parties (the Social Democratic Party, the Green Party, and the Left party) but also the participating NGOs. Academically speaking, the left-leaning countermovement can best be described as the definitional counterpart to the right-leaning movement. Supporters are explicitly pro-immigration and prodemocratic, and they reject populism.

\section{Setting}

\section{Berlin}

On May 27, 2018, the AfD organized a protest in Berlin under the banner "Germany's Future" (Zukunft Deutschland). ${ }^{9}$ The protest's stated goal was to express dissatisfaction with Angela Merkel's administration. The AfD's leadership officially encouraged its supporters to attend the protest and, to some extent, organized transport from regions outside of Berlin. The protest was promoted to AfD supporters through internal communication channels and on social media. In response to the protest announcement of the AfD, the political alliance "Stop Hatred" (Stoppt den Hass) organized a counterprotest on the same day in Berlin. Stop Hatred was supported by all major left-leaning parties and Germany's main trade-union association, as well as a host of civil society organizations, including Berlin's club scene. In total, roughly 5,000 people turned out for the AfD protest, and 25,000 people joined the counterprotest.

\section{Erfurt}

A year later on May 1, 2019, the AfD initiated another protest in Erfurt, the state capital of Thuringia. Labor day protests are traditionally organized by left-leaning organizations. The AfD protest was therefore an attempt to set a counterpoint to many left-wing protests across Germany on the same day. The Erfurt protest, too, featured prominent right-wing politicians and was advertised in regional AfD chapters. The political alliance "Stand Together" (Zusammenstehen) responded to the announcement of the AfD by organizing a counterprotest. Similar to the counterprotest in Berlin, the Erfurt alliance was supported by major national and

\footnotetext{
${ }^{9}$ The fact that the protest was organized by the AfD raises the question of whether the event can be conceptualized as a "movement" event or whether it is simply a party event. It is important to note that the AfD is not simply a party but widely described as the political arm of a broader movement. As Berbuir, Lewandowsky, and Siri write, "the AfD is not a right-wing populist party in itself but may be a right-wing populist movement in the making" (2015, 173). Importantly, although the event was organized by the party, the participating protesters came from a wide variety of right-leaning and far-right groups.
}

regional left-leaning parties, the main union confederation, and the regional chapter of the Christian Democratic Union. Roughly 1,000 AfD supporters turned out who were opposed by about 4,000 activists in the counterprotest.

\section{Sample}

To analyze how turnout in a potential activist's own protest and in the opposing movement's protest affect her likelihood to turn out, we relied on an online recruitment procedure. The recruitment of potential activists for an experimental intervention is challenging, particularly on the political right. Therefore, we devised a targeted recruitment strategy using online ads distributed via Facebook. The ads, which are shown in Figure A1, invited individuals to take part in a scientific survey regarding protest behavior. The ads were geotargeted to individuals that reside within 80 kilometers of Berlin or Erfurt, respectively. We advertised the banners 13 and 14 days prior to and on the day of the protests in Berlin and Erfurt.

To reach potential protesters on the political left and right, we targeted individuals who had expressed interest in political key words in the past. On the political right, we included terms such as "Alternative for Germany AfD," "National Democratic Party of Germany," or "Right-Wing Politics." To reach the political left, we targeted terms including "Anti-Fascist Action," "Young Socialists in the SPD," "Left-Wing Politics," and "Anti-Racism." For both groups, we used Facebook's extension to include individuals who did not meet the explicit keywords but were likely to be suitable participants. We discuss the two samples in SI Section A, where we highlight broad comparability across the two contexts and significant prior experience in protesting, suggesting we succeeded in recruiting a sample of potential activists. The ethics of implementing a field experiment among potential political activists are discussed in SI Section C. The data collected for this study are provided in Hager et al. (2021b).

\section{Experimental Design}

All targeted individuals who clicked on the ad were guided to an online survey. To maximize comparability, the survey was nearly identical across the political right and left. After obtaining informed consent, subjects were first administered eight descriptive questions regarding their background and motivation to protest. ${ }^{10}$ We then implemented the following experimental design.

\footnotetext{
${ }^{10}$ We measured respondents' age, gender, education, and place of residence. We then asked four political questions, measuring respondents' party identification and their motivation to protest. The protest items measured respondents' agreement with the statement that they (a) "primarily go protesting to ignite political change" and (b) "primarily go protesting to express their views." Finally, we asked whether respondents think the AfD is (a) "an important opportunity for Germany" (only asked on the right) or (b) "a threat to democracy" (only asked on the left).
} 
TABLE 1. Expert Forecasts Regarding Turnout at Right-Wing Protests and Left-Wing Counterprotests

\begin{tabular}{lll}
\hline & Berlin & Erfurt \\
\hline Treatment 1: AfD high, Counter low & AfD: 10,000 & AfD: 3,000 \\
& Counter: 5,000 & Counter: 1,000 \\
Treatment 2: AfD low, Counter high & AfD: 5,000 & AfD: 1,000 \\
& Counter: 10,000 & Counter: 3,000 \\
Treatment 3: AfD low, Counter low & AfD: 5,000 & AfD: 1,000 \\
& Counter: 5,000 & Counter: 1,000 \\
Treatment 4: AfD high, Counter high & AfD: 10,000 & AfD: 3,000 \\
& Counter: 10,000 & Counter: 3,000 \\
\hline Note: Table 1 shows the four treatment conditions in Berlin and Erfurt, respectively, to which subjects were randomly assigned. The
\end{tabular}

\section{Pretreatment Beliefs about Turnout}

First, we elicited respondents' pretreatment beliefs about the turnout at their own protest and the counterprotest: ${ }^{11}$

1. Right-wing protest turnout: "The AfD has organized a protest [on May 27 in Berlin]. It is expected that members of right-wing movements (PEGIDA and the identitarians) will also join them. How many protesters do you think will attend the AfD protest?"

2. Left-wing counterprotest turnout: "In response to the AfD protest, the alliance ["Stop Hatred"] has called for a counterprotest on [May 27]. The alliance will, i.a., be supported by local chapters of the Greens, the Left and the SPD. How many counterprotesters do you think will protest against the AfD?"

\section{Treatment}

Next, we randomly assigned respondents to either low or high forecasts regarding turnout in both their own and the opposing protest. To obtain credible low and high forecasts for the two protests in the two contexts, we contacted several sources familiar with the respective organizers (both partisan and neutral observers such as the police, journalists, and academics; more details are given in Appendix Section D). In Berlin, the low turnout forecast for both protests was 5,000 and the high turnout forecast was 10,000. In Erfurt, the low forecast was 1,000, while the high forecast was 3,000. We then randomly ${ }^{12}$ provided subjects with a forecast for their own protest as well as the opposing protest, which was either high or low. In sum, there were four different treatments to which subjects were randomly assigned, which are summarized in Table 1. The

\footnotetext{
${ }^{11}$ We report the measures used in the Berlin sample. The measures implemented in Erfurt are virtually identical, only the dates and names are different.

${ }^{12} \mathrm{We}$ used simple random assignment, which created excellent covariate balance in the pooled sample (Table A7), the right-wing sample (Table A8), and the left-wing sample (Table A9).
}

turnout forecasts were shown to respondents using a bar chart, which is depicted in Figure 1.

\section{Outcome}

After providing the treatment information, we measured two primary outcomes of interest. First, we elicited respondents' posttreatment beliefs about turnout at the right-wing protest as well as the turnout at the left-wing counterprotest. Obtaining the posttreatment beliefs about protest turnout allows us to verify that our treatment indeed shifted respondents' beliefs in the intended direction, on average. The posttreatment measure was as follows:

- Posttreatment belief: "Given this information, what do you think how many people will participate in the respective protests?"

Second, we elicited a continuous measure of respondents' willingness to take part in their respective protest. The item was measured on a four-point scale, ranging from certain nonparticipation to certain participation:

- Willingness to participate: "How likely is it that you will participate in the [AfD protest/"Stop Hatred" protest] on May 27th?"

Finally, the survey also included an item asking respondents to send in a photo of themselves at the protest. The final outcome serves as a behavioral measure of protest attendance, which we discuss below. To make the treatment effects comparable across contexts, we standardize all variables at the protest-city level. While not preregistered, this is a necessary step to make the size of treatment effects comparable across different contexts. ${ }^{13}$

\footnotetext{
${ }^{13}$ Reassuringly, all results are robust to not standardizing the outcome variables (Table A20).
} 


\title{
FIGURE 1. Treatment Screen
}

\section{Expert opinions}

\begin{abstract}
We asked several experts about the number of participants in both protests. One of the consulted experts expects about 10,000 pro AfD protesters to participate. Another expert expects that about 10,000 counter protesters will participate.

This means that experts believe that the number of counter protesters will be the same size as the number of of pro-AfD protesters.
\end{abstract}

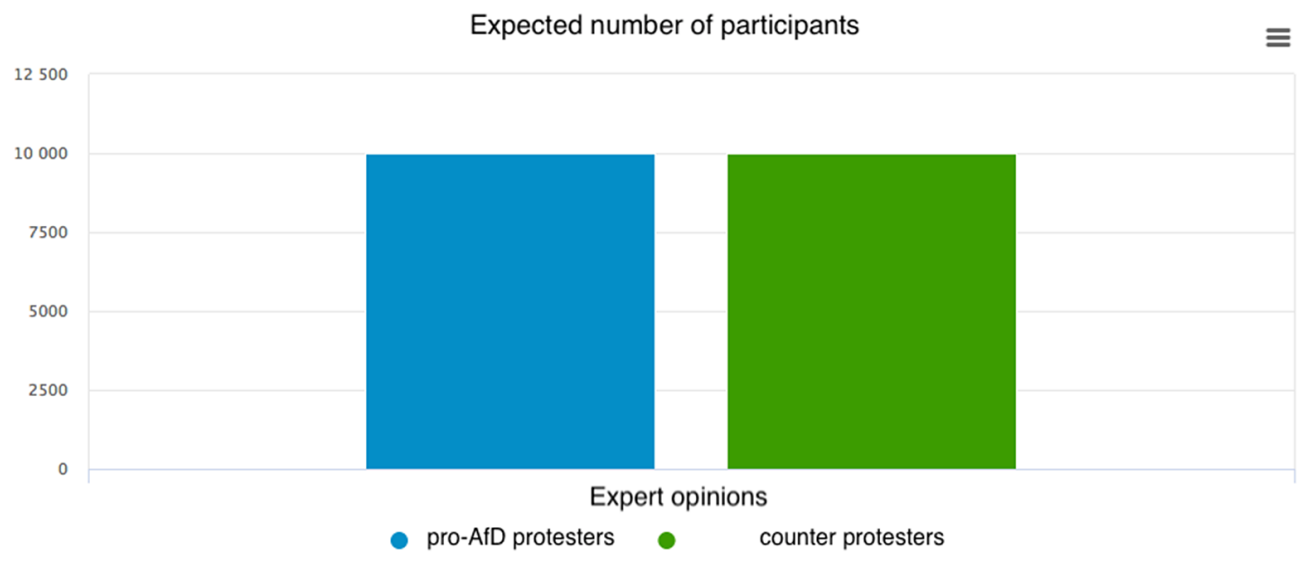

Note: Figure 1 shows an exemplary treatment screen for the experiment conducted in Berlin (translated).

\section{RESULTS}

To estimate the influence of information about one's own and the opposing protest's turnout on a respondent's protest participation intentions and behavior, we estimate the following equation using ordinary least squares (OLS). ${ }^{14}$

$$
\begin{aligned}
y_{i}= & \alpha_{0}+\alpha_{1} \text { Own protest high turnout } \\
& +\alpha_{2} \text { Opposing protest high turnout }_{i}+X_{i}+\varepsilon_{i},
\end{aligned}
$$

where $y_{i}$ is respondent $i$ 's intention to participate in her own preferred protest. Own_protest_high_turnout $t_{i}$ takes the value one if respondent $i$ received the higher expert forecast for her own protest and zero if she received the lower forecast. Opposing_protest_high_turnout $t_{i}$ takes the value 1 if $i$ received the higher expert forecast about opponent turnout and zero if she received the lower forecast. ${ }^{15}$ Conceptually speaking, the model thus compares individuals who were informed about high

\footnotetext{
${ }^{14}$ We use OLS instead of ordered logit as our main specification to facilitate interpretation of the magnitude of treatment effects. This is in line with the predominant view in the econometric and statistical literature that OLS is the best estimator for analyzing experimental data (Angrist and Pischke 2008; Freedman 2008). That said, our results are robust to using ordered logit regressions, which we show in Table A11.

${ }^{15}$ An alternative way of analyzing the data involves the inclusion of an interaction term between receiving a high forecast for the own protest and a high forecast for the opposing protest. Table A12 shows
}

turnout in their own protest/the opposing protest with those who were informed about low turnout. $X_{i}$ is a vector of all available predetermined and preregistered control variables, which are shown in Table A2. The vector includes age, gender, a dummy for completing vocational or university education, a dummy for left-leaning respondents, a dummy for Berlin, a dummy for previous protest experience, a measure of perceptions about the AfD, a measure of beliefs about the effectiveness of protests, and a measure of whether the respondent mainly participates in protests to express her opinion. In our main analysis, we pool data across both protests but separately analyze responses of supporters of the rightwing and left-wing countermovement.

\section{Own Movement's Turnout and Protest Intentions}

We begin by assessing the effect of respondents' own protest's size on protest intentions. Table 2 shows that both left- and right-leaning potential activists are highly responsive to information about turnout in their own political movement. Importantly, however, the patterns of strategic interactions vary substantially between the right-wing movement and the left-wing countermovement. When a right-leaning

that there are no significant interaction effects. To increase statistical power, we do not include the interaction term in the main model. 
TABLE 2. Effect of Turnout Information Treatments on Protest Intentions

Protest intentions (z)

Panel A: Right-wing protest sample

\begin{tabular}{lc}
\hline Own protest high turnout & $-0.147^{\star \star}$ \\
& $(0.062)$ \\
Opposing protest high turnout & 0.039 \\
& $(0.062)$ \\
Observations & 567 \\
\hline
\end{tabular}

Panel B: Left-wing counterprotest sample

\begin{tabular}{lc}
\hline Own protest high turnout & $0.172^{\star \star}$ \\
& $(0.078)$ \\
Opposing protest high turnout & 0.076 \\
& $(0.078)$ \\
Observations & 897
\end{tabular}

Note: The Table shows coefficients and standard errors of the main OLS regression of the indicated outcome on the own protest high turnout and opposing protest high turnout treatment dummies, which indicate when a respondent was given the high turnout forecast for the respective protests in a given context. "Protest intention" captures respondents' intention to participate in their own protest, measured on a four-point scale $(4=$ Yes; $3=$ uncertain, but probably; $2=$ uncertain, but probably not; $1=$ no), which is standardized at the city-protest-level. Panel A includes the supporters of the right-wing movement. Panel B includes supporters of the left-wing countermovement. All preregistered controls are included. ${ }^{\star} p<0.10 ;{ }^{\star *} p<0.05 ;{ }^{\star \star *} p<0.01$.

respondent receives a forecast about high turnout in her own protest, she decreases her participation intentions by $0.15 \mathrm{SD}$ relative to the control group with a low forecast. Thus, among the political right own engagement and peer engagement are strategic substitutes. Put differently, as expected turnout in the own protest increases, supporters of the right-wing movement become less likely to protest. ${ }^{16}$

The picture is reversed on the political left. When left-leaning respondents receive a forecast about high turnout in their own protest, they increase their participation intentions by $0.17 \mathrm{SD}$ relative to the control group with a low forecast. On the left, supporters' own engagement and peer engagement are thus strategic complements. All estimates are statistically significant and substantively sizable. To see this more readily, we dichotomize the protest intention variable in Table A20. Doing so shows that right-leaning respondents who are presented with a high predicted turnout at their own protest are 6.1 percentage points $(15 \%)$ less likely to protest compared with respondents who received a low turnout forecast. By contrast, leftleaning respondents who see high predicted turnout at their own protest are 5.8 percentage points $(23 \%)$ more likely to protest compared with respondents who received a low turnout forecast.

\footnotetext{
${ }^{16}$ We show that the information, indeed, led individuals to change their beliefs about turnout-i.e., a manipulation check-see Section D.1.
}

\section{Opposing Movement's Turnout and Protest Intentions}

How does information about the estimated turnout of the opposing protest affect potential activists' decision to protest? We next analyze whether respondents' intended participation changes as a result of receiving a forecast about high opponent turnout. Table 2 shows that this is not the case. When given information about higher turnout in the opposing protest, right- and leftleaning respondents do not change their protest intentions. The estimates are insignificant and small (0.04 and $0.08 \mathrm{SD}$, respectively). Taken together, protest intentions are thus seemingly unaffected by opponent turnout. Importantly, the small coefficients are highly similar across both groups of the political spectrum, suggesting no political heterogeneity.

\section{Protest Participation}

The outcome data used thus far only capture respondents' intentions to protest. While intentions are arguably a relevant outcome, which have been shown to predict protest behavior (Hager et al. 2019), one may still wonder whether respondents also changed their actual participation. To address this question, the survey gave respondents the opportunity to provide the research team with their email address and send in a photo of themselves at the respective protests. Unfortunately, only a small subset of respondents sent a photo for the protest in Berlin, and no photo was sent in Erfurt. One potential reason for the low number of pictures are strong privacy concerns in Germany, given that respondents were required to share their email address with the research team. ${ }^{17,18}$

\footnotetext{
${ }^{17}$ We observe a strong correlation between intentions to protest, actual protest participation, and past protest attendance (see Table A13). A one-standard-deviation increase in protest intentions is associated with 0.11 standard deviations more observed protest attendance $(p<0.01)$. These results are robust to controlling for the prespecified set of controls (column 2 of Table A13). Past protest behavior provides another validation that our measure of intentions captures an individual's propensity to protest. Table A15 shows that a one-standard-deviation increase in past protest behavior is associated with 0.34 standard deviations higher reported protest intentions. Moreover, Table A16 shows that the relationship does not vary across subgroups, suggesting that the measure works similarly across our sample. While these results are only correlational and might not account for all unobservable factors that mediate the relationship between intentions and behavior in either direction, the observed patterns suggest that intentions as measured by our survey do seem to capture individuals' propensity to attend protests.

${ }^{18}$ There is the obvious problem of selection bias in that there is selection into sending a picture of protest participation. Reassuringly, observable characteristics of participants are not predictive of who sent back pictures, even conditional on protest intentions. The exceptions are being a right-wing supporter, which reduces the likelihood of sending pictures (potentially due to negative treatment effects) or being better educated which increases the likelihood of sending a picture (column 2 of Table A13). Similarly, we do not observe significant differences between individuals who sent and did not send pictures (Table A14). However, due to the small sample size of received pictures, these results should be interpreted with caution.
} 


\section{TABLE 3. Effect of High Turnout in Own Protest on Actual Protest Behavior (Berlin)}

Sent photo $(z)$

\section{Panel A: Right-wing protest sample}

\begin{tabular}{lc}
\hline Own protest high turnout & -0.085 \\
& $(0.104)$ \\
Observations & 417 \\
\hline
\end{tabular}

Panel B: Left-wing counterprotest sample

Own protest high turnout $0.192^{*}$

Observations

542

Note: The Table shows coefficients and standard errors of an OLS regression of the indicated outcome on the respective treatment dummies. "Sent photo $(z)$ " is the standardized value of a dummy variable that takes the value one if a respondent actually sent a photo of their participation in the protest to the research team. Panel $A$ shows data from supporters of the rightwing protest. Panel $B$ shows data from supporters of the left-wing counterprotest. All preregistered control variables are included. This sample is restricted to the Berlin protest. ${ }^{*} p<0.10 ;{ }^{*} p<$ $0.05 ;{ }^{* * *} p<0.01$.

Reassuringly, we find similar treatment effects on respondents' actual behavior for the high turnout in their own movement treatment, which showed strong attitudinal effects above. Table 3 shows that rightleaning respondents are $0.09 \mathrm{SD}$ less likely to send in a photo from the protest when informed about large turnout in their own protest. By contrast, left-leaning respondents are significantly more likely $(0.19 \mathrm{SD})$ to send in a photo when primed with high turnout in their own protest than with a low forecast. The behavioral data thus corroborate the finding from above: leftleaning potential activists increase their engagement as peers become more engaged, whereas right-leaning potential activists tend to free-ride. ${ }^{19}$ But, as stated, we were only able to measure behavior in Berlin and the result is only significant on the political left. ${ }^{20}$

\section{MECHANISMS}

Why do right-leaning potential activists become less inclined to engage as their peers become more active whereas the reverse holds for potential activists that support the left-leaning countermovement? Evidence on causal mechanisms is necessarily tentative and was not pre-registered. Below, we attempt to trace the

\footnotetext{
${ }^{19}$ One caveat in this context is selection bias in that there can be selection into sending a picture after participating in the protest. For instance, people with fewer privacy concerns are more likely to send in a picture.

${ }^{20}$ The sample of activists that return pictures is too small to draw strong conclusions about the selection into becoming active. However, we can compare the characteristics of individuals who intend to protest and are more or less likely to act on their intentions. Table A17 shows that the differences in attitudes and demographics between these groups are generally insignificant.
}

aforementioned micro-, meso- and macro-level channels. Given that we find no effect of the opposing protest's size, we focus on explaining the effect of potential activists' own protest's size on their willingness to take to the streets. We discuss the generalizability of our findings beyond the two cities in a dedicated section.

\section{Micro Level: Social Connections to the Movement}

In the theoretical section, we argued that rising turnout in one's own protest exacerbates free-riding incentives but that it also reinforces social motives to attend. To explore whether the left, indeed, can offset free-riding incentives on the basis of social motives, we provide three pieces of evidence. First, if social motives are behind the observed heterogeneity, we would expect individuals on the left to be more connected to the movement as compared with individuals on the right. To explore this conjecture, we collected additional survey evidence seven weeks after the Erfurt protests took place. ${ }^{21}$ Table A6 confirms that supporters of the left-wing countermovement know substantially more people who previously participated in protests compared with supporters of the right-wing protest $(p=$ 0.057).

Second, if social motives are behind the observed heterogeneity, one would also expect left-leaning respondents to be more committed to the movement. As individuals who are more committed to the movement are likely to have protested in the past, we use past protest experience as a proxy for commitment. Tables A3 and A4 confirm that left-leaning potential activists, indeed, have attended significantly more protests compared with right-leaning potential activists (6.1 vs. 4.8 previous protests, respectively).

Third and related, if social motives offset free-riding incentives, we would expect treatment effects for more committed individuals to be more positive. Evidence in line with this conjecture is provided in Table A18. Treatment effects are 2.6 times larger among experienced respondents compared with inexperienced respondents ( 0.16 vs. $0.06 \mathrm{SD})$. The difference between experienced and inexperienced study participants is even more pronounced among supporters of the AfD ( -0.08 vs. $-0.4 \mathrm{SD})$.

We should caution, however, that sympathizers of different political movements may also differ in their demographic characteristics, which could explain the differences in effects we observe. Participants in our sample do differ in several demographic dimensions. For example, left-leaning respondents are younger and they are less likely to be male, though they do not differ in terms of education (see Tables A3 and A4). To test

\footnotetext{
${ }^{21}$ In an effort to keep this new sample as comparable as possible to the two experimental samples, we recruited potential activists using the same Facebook ads and recruitment procedure described in the sample section. Reassuringly, in terms of attitudes and demographics, the sample appears highly similar to the experimental samples (see Table A5).
} 
whether these differences mediate the observed treatment effects, we estimate a linear regression that includes interactions of the treatment dummies with all available covariates. Table A19 shows that none of the treatment-covariate interactions is statistically significant. Demographic characteristics are thus rather unlikely to drive the observed differences in treatment effects across movements. ${ }^{22}$

\section{Meso Level: The Social Nature of Protests}

In the theoretical section, we argued that rising turnout may mean that protests provide different levels of enjoyment across the political left and right. This is in line with both qualitative and quantitative evidence from our setting. From a qualitative perspective, the four protests did differ markedly in their social nature.

For example, in Berlin, the club and party scene organized a procession under the motto "Blow away the AfD," which featured electronic music and a large party. One headline in the German public radio read "Music and Party against the Right." ${ }^{23}$ In Erfurt, the leftwing counterprotest featured a free-to-attend concert with German pop stars. By contrast, the right-leaning protests in both cities did not feature any music or other entertainment, focusing exclusively on speeches by prominent far-right politicians. It thus seems plausible that the left-wing counterprotests, in our setting, provided greater enjoyment value to their supporters, which arguably rises as protests become larger.

To confirm that potential activists on the left, indeed, derived greater enjoyment from the protests compared with individuals on the right, our survey included a question on whether participants perceived protests to be "fun." As Table A6 shows, supporters of leftwing counterprotests are significantly more likely to view protest as fun events compared with supporters on the right $(p<0.01)$. The heterogeneity could thus plausibly have contributed to the differences in treatment effects we observe across the political right and left. That said, while the difference between the leftand right-wing sample is stark, it is only based on a sample of four protests (two in Erfurt and two in Berlin). We discuss scope conditions - that is, the degree to which left-wing protests generally provide greater enjoyment value to their followers compared with the right - in a dedicated section below.

\section{Macro Level: Societal Support}

Finally, we turn to macro-level variables, which operate at the level of society. In the theoretical section, we argued that rising turnout translates into increased media and societal attention, which raises the likelihood to receive societal praise or scorn, depending on the movement. In

\footnotetext{
${ }^{22}$ We must caution, however, that we only observe a limited set of variables and cannot account for unmeasured or unobservable confounders.

23 "Musik und Party gegen Rechts." Deutschlandfunk Kultur, May 27, 2018.
}

the following we provide evidence that the left-wing counterprotest, indeed, enjoyed more support among the general population than the right-wing protest.

Before presenting quantitative evidence, it is worth mentioning that Germany's contemporary political right is a movement that challenges the status quo. This is worth mentioning given that, for much of the 1970s, challenger movements in Europe were located on the political left. Movements fought for women's rights, ecological justice, peace and, in particular, nuclear disarmament (Kriesi 1989). Since the late 1980s, however, the challenger status has slowly moved toward the political right. As the demands of the 1970s and 80s became the status quo, a steadily growing number of populistright parties began to voice opposition to a globalizing, liberal polity (de Vries and Hobolt 2020; Mudde 1996).

One critical difference between a (challenger) movement and the countermovement is the size of the support base. Challenger movements object to the established majority opinion. Societal support for the challenger movement is therefore, at least initially, comparatively small. The reverse holds for the establishment movement, which defends the status quo and is thus supported by more citizens. In our setting, for instance, turnout at the left-wing counterprotest was about three to five times as large as that of the challenger movement. (We show that this pattern holds across Europe more broadly when discussing generalizability.)

To assess whether society, indeed, disapproved of the right-wing protests in Berlin and Erfurt but approved of the left-wing counterprotests, we fielded a representative population-level survey (details are given in Section D.2). We asked "In May 2018, the AfD organized a protest against the federal government in Berlin. Do you scorn or praise the protesters?" On average, only $20 \%$ of respondents stated that they would praise the protesters, but $54 \%$ would scorn them (Panel A of Table A21). The picture is reversed on the left. When asking "In May 2018, the AfD organized a protest against the federal government in Berlin. Various groups then organized a counterprotest. When asked, "Do you scorn or praise the counterprotesters?" $43 \%$ would praise the counterprotesters, but only $24 \%$ of respondents would scorn them.

In a second step, we studied respondents' perceptions about media coverage of the protests in Berlin (which were widely discussed in German media), which allows us to tap into perceptions about societal approval. Specifically, we asked respondents whether they thought that the media covered the 2018 protests positively or negatively. We find that $47 \%$ of respondents believed that the AfD protests were covered negatively and only $14 \%$ perceived the coverage to be positive. For the left-wing counterprotest, $35 \%$ perceived positive media coverage and 19\% perceived coverage to be negative. Overall, our evidence is in line with other studies showing that approval of the left and disapproval of the right is symmetric and, importantly, not hidden (Lehrer, Juhl, and Gschwend 2019), contrasting studies that point to clandestine support (Borstel and Heitmeyer 2012). 
FIGURE 2. Turnout in Right-Wing Protests and Left-Wing Counterprotests in Germany

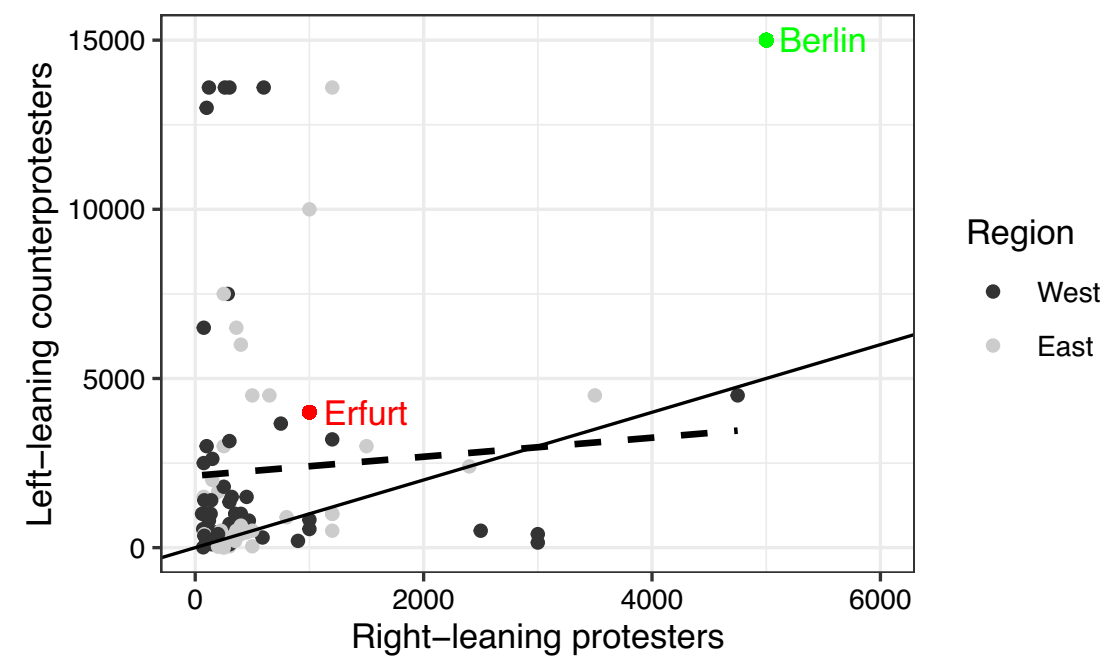

Note: The Figure plots the turnout at right-wing protests and left-wing counterprotest in Germany from 1950 to 2002 based on PRODAT data. To ease the visualization, we winsorize protest turnout at the 95th percentile. The red and green dots, respectively, show turnout in our two settings. The solid black line represents equal sizes of right-wing and left-wing counterprotests. The dashed line represents a fitted linear regression.

\section{GENERALIZABILITY}

To what extent are the two cases, Berlin and Erfurt, representative of the broader universe of right-wing protests and left-wing counterprotests in Germany and beyond? What scope conditions do the empirical findings imply and how likely are they to hold in other settings?

\section{Generalizability}

We begin by considering how the two cases compare in terms of size to the universe of right-wing protest and left-wing counterprotests in Germany. Figure 2 plots data from right-wing protests and left-wing counterprotests from 1950 to 2002 based on PRODAT (Rucht, Hocke, and Ohlemacher 1992) and adds our two cases in green (Berlin) and red (Erfurt), respectively. This analysis provides two pieces of evidence. First, since the 1950 s, right-wing protests have consistently been smaller than left-wing counterprotests. The empirical evidence presented in Figure 2 suggests that it is not unusual to see relatively small right-wing protests and large left-wing counterprotests. The two cases we study are thus no exception. Second, when plotting our two cases, Erfurt turns out to be rather typical: it lies close to the regression line and shows moderate turnout on both sides. Berlin, on the other hand, constitutes a rather unusual case, particularly when considering the right's large turnout. With this heterogeneity in mind, the fact that we find similar evidence across both a typical and an atypical case makes us cautiously optimistic regarding the generalizability of the findings. That said, we must caution that the protest data only lasts until 2002. Reassuringly, Table 4 shows that far- right protests since 2002 show similar turnout levels in Germany (average of 2,958 participants), whereas leftwing protests, again, are significantly larger (average of 27,741 participants). Given these numbers, the Berlin protest is less of an outlier relative to other more recent protests.

A second important variable is the geographic location of the protests. Berlin is the German capital and sees many protests. Erfurt, by contrast, is a small university town with a lively left-leaning scene. How many protests take place in both cities, respectively? To distill further contextual variables, we make use of the POLCON dataset (Kriesi et al. 2020). The dataset covers all protests from 2002 to 2015 across a range of European countries. ${ }^{24}$ Panel A of Table 4 shows that Berlin is no unusual venue for right and left-leaning protests: $38 \%$ of all left-leaning protests in Germany take place in Berlin and $20 \%$ of all right-leaning protests. Erfurt, by contrast, is a rather unusual location. That said, comparable smaller East German college towns - such as Jena or Leipzig - are responsible for $19 \%$ of all right-leaning protests. Taken together, the two contexts are thus not unusual compared with other protest locations in Germany. The locations of the protests in our study are also not unusual in a broader European context: $28 \%$ of protests in five large western European Democracies take place in the nations' capital and 32\% take place in university cities other than the capital. Thus, cities similar to Berlin and Erfurt account for about $60 \%$ of protest locations in these countries.

\footnotetext{
${ }^{24}$ Unfortunately, the data do not indicate whether a counterprotest took place.
} 
TABLE 4. Right- and Left-Wing Protests in Germany and Europe

\begin{tabular}{lrrr}
\hline & $\begin{array}{c}\text { All } \\
\mathbf{( 1 )}\end{array}$ & $\begin{array}{c}\text { Left-wing } \\
\mathbf{( 2 )}\end{array}$ & $\begin{array}{c}\text { Right-wing } \\
\mathbf{( 3 )}\end{array}$ \\
\hline Panel A: Protests in Germany & & & \\
\hline Average participants & $13,930.81$ & $27,741.33$ & $2,958.21$ \\
Xenophobic issues (\%) & 23.31 & 0.00 & 84.40 \\
Berlin (\%) & 23.57 & 38.16 & 20.18 \\
University city (\%) & 36.22 & 25.00 & 37.61 \\
East German university city (\%) & 12.65 & 9.21 & 19.27 \\
Erfurt (\%) & 0.39 & 1.32 & 0.00 \\
\hline
\end{tabular}

Panel B: Protests in large western European democracies

\begin{tabular}{lrrr}
\hline Average participants & $20,871.50$ & $48,618.59$ & $33,979.33$ \\
Xenophobic issues (\%) & 8.25 & 0.00 & 44.79 \\
Capital city (\%) & 28.33 & 30.52 & 27.41 \\
University city (\%) & 31.64 & 32.97 & 29.34 \\
\hline
\end{tabular}

Note: Panel B plots the indicated variables for protests across all large western European democracies (United Kingdom, Italy, Spain, France, and Germany). Panel A plots the indicated variables for protests in Germany. Column (1) uses all protests. Column (2) shows protests initiated by left-wing parties. Column (3) shows protests initiated by right-wing parties. The numbers are based on all protests between 2002 and 2015 captured by POLCON.

\section{Scope Conditions}

Even if the two protests are comparable in terms of location and size to the broader universe of protests, the mechanism section implies important scope conditions that undergird the effect of turnout in a potential activist's own protest on participation intentions. In particular, in the mechanism section, we pointed out that social motives arguably mediate the observed treatment effects, which operate at the micro, meso, and macro levels. Below, we characterize to what extent these scope conditions are likely to hold across right- and left-leaning protests in Germany more broadly.

\section{Micro Level: Social Connections to the Movement}

In Section 5, we showed that left-leaning potential activists in our sample were better connected to their movement than right-leaning potential activists (Table A6), which helps explain the positive treatment effect on the left. Are supporters of left-leaning movements generally better connected to their movement than right-leaning counterparts? To answer this question, we leverage data on the universe of protests in Germany (as well as other European countries). As Table 4 shows, left-leaning protests are significantly larger than right-leaning protests. This pattern also holds when focusing exclusively on right-wing protests and left-wing counterprotests (see Figure 2). This evidence does not mean that left-leaning protesters are necessarily better connected. But, to our mind, it makes it likely that social motives loom larger on the political left, inducing left-leaning individuals to attend in the face of growing turnout.

\section{Meso Level: The Social Nature of Protests}

In the mechanisms section, we also showed that leftleaning potential activists derive greater enjoyment from protests, which helps explain the observed heterogeneity. To explore whether left-leaning protests provide greater enjoyment value at large, we analyze newspaper articles covering protests and counterprotests in Germany. Specifically, we collected all newspaper articles from 2016 to 2020 that discuss right-wing protests and counterprotests in Germany (details are provided in Section D.3). We then applied natural language processing to the articles to capture whether the two types of protests are commonly described as involving fun elements such as music and parties. Figure A3 shows that significantly more articles describe left-wing counterprotests in enjoyment-related terms, suggesting that the meso-level scope condition is likely to apply across Germany more broadly.

\section{Macro Level: Societal Support}

In the mechanisms section, we relied on a general population survey to demonstrate that individuals participating in the Berlin protests in 2018 likely received scorn (on the right) and praise (on the left) from the general population and the media. We provide three pieces of evidence that the patterns generalize to rightwing protests and respective counterprotests in Germany more broadly. First, Panel B of Table A21 leverages data from the same survey, which indicates that scorn and praise toward right-wing and left-wing protesters-in general-is very similar to the levels reported for the Berlin protest. ${ }^{25}$ Second, perceived

\footnotetext{
${ }^{25} 54 \%$ of the general population would scorn participants for attending right-leaning protests, but only $19 \%$ would scorn counterprotesters. By contrast, $21 \%$ of respondents would praise right-wing protesters but $50 \%$ would praise counterprotesters. The individual level correlation between attitudes toward the 2018 protest and generalized attitudes are 0.83 for the right and 0.56 for the left.
} 
media coverage of protests in general is also very similar to the perceived coverage of the Berlin protests (see Panel B of Table A22). Third, to go beyond perceptions of media coverage, we conducted a content analysis of newspaper articles discussing right-wing protests and counterprotests. As Figure A4 shows, right-leaning protests are described in significantly more negative terms than left-leaning counterprotests. Reassuringly, this observed pattern of societal stigma for right-wing movements is also found in other European countries (Meadowcroft and Morrow 2017; Rydgren 2010), suggesting that the macro-level scope condition generalizes beyond our immediate context.

\section{CONCLUSION}

This paper studied strategic interdependence across movements and countermovements. We implemented a field experiment among 1,464 left- and right-wing potential activists ahead of two political protests and counterprotests in Germany. Potential activists were randomly exposed to low or high official estimates about their own and the opposing protests' size. Our results show that the size of the opposing protest has no effect on protest intentions. However, when information indicated that the own protest was large, rightleaning potential activists became less likely whereas left-leaning potential activists became more likely to protest. We argue that this heterogeneity can be explained on the basis of different social motives across the political left and right, which operate at three levels: left-leaning supporters are more connected to the movement (micro level), left-leaning protests provide greater enjoyment (meso level), and society at large favors left-leaning protests (macro level). All three mechanisms mean that, on the left, rising turnout leads individuals to become more likely to engage, while the reverse holds on the right.

The main findings of this paper are relevant for our understanding of the dynamics of political movements and countermovements in two ways. First, we find that potential activists seem unresponsive to the engagement level of the opposing group. This result helps explain how fringe movements can obtain power even when facing a large countermovement: potential activists seemingly disregard the competition. In light of this finding, it strikes us as a fruitful avenue for future research to scrutinize how the size of an activist's own movement (independent of turnout at protests or the size of the opposing movement) affects her protest behavior. Do followers of fringe movements-as opposed to large-scale movements-show different patterns of within-movement strategic interactions; if so, why? Moreover, do the patterns of strategic interactions extend to other types of events or actions organized by movements?

Second, the academic literature has found substantial heterogeneity in patterns of strategic interactions within the own group across a number of contexts. Some authors found strategic substitutability (Cantoni et al. 2019; Hager et al. 2021a), but others uncovered complementarity in engagement choices (Bursztyn et al. 2021; González 2020). The fact that our study found different patterns of strategic interactions within the same context shows that a universal regularity is unlikely to exist. Still, we believe that cross-national studies - analyzing several movements at once-might help uncover important variables that make sense of the observed heterogeneity in strategic interactions. According to our study, particularly fruitful prisms to explain the varied results in the literature are (a) social connections, (b) enjoyment values, and (c) societal support.

More broadly, our research endeavor points to a series of open questions in the context of movement and countermovement dynamics. First, our work suggests that how people expect the media to report on their movement may play an important role in shaping protest intentions. Second and related, a better understanding of the relative importance of different reference groups - such as friends, colleagues, relatives, or society at large-strikes us as an important avenue for research. If protesters are sensitive to societal support, from which individuals do they expect to receive praise? Finally, our findings suggest that a more systematic assessment of the enjoyment value provided by protests is worthy of detailed inquiry. Of particular interest is whether such enjoyment (e.g., a concert) is contingent on existing social connections or whether it can spark activism on its own.

\section{DATA AVAILABILITY STATEMENT}

Data that support the findings of this study are openly available at the American Political Science Review Dataverse: https://doi.org/10.7910/DVN/MUSFYH. Limitations on data availability are discussed in Appendix Section B. We preregistered the analysis on the AEA RCT repository (trial id AEARCTR-0003017).

\section{SUPPLEMENTARY MATERIALS}

To view supplementary material for this article, please visit http://doi.org/10.1017/S0003055421001131.

\section{ACKNOWLEDGMENTS}

We thank Rafaela Dancygier, Amaney Jamal, Johannes Abeler, Peter Andre, Leonardo Bursztyn, Daniel Bischof, Felix Chopra, Joshua Dean, Julien Labonne, Matt Lowe, Muriel Niederle, Pablo Querubin, Andreas Stegman, and seminar participants at the Annual Meeting of the American Political Science Association in 2019 and the Free University of Berlin for very helpful comments. Anna Lane, Till Tietz and Katharina Teresa Dürmeier provided excellent research assistance. 


\section{FUNDING STATEMENT}

This research was partially funded by the following sources:

Roth: Funded by the Deutsche Forschungsgemeinschaft (DFG, German Research Foundation) under Germany's Excellence Strategy-EXC 2126/1390838866.

Hensel: Economic and Social Research Council of the UK.

\section{CONFLICT OF INTEREST}

The authors declare no ethical issues or conflicts of interest in this research.

\section{ETHICAL STANDARDS}

The authors declare that the human-subjects research in this article was reviewed and approved by the Ethics Committee at the University of Oxford (ECONCIA1819-04). Details and certificate numbers are provided in the text and the appendix. The authors affirm that this article adheres to the APSA's Principles and Guidance on Human Subject Research.

\section{REFERENCES}

Amenta, Edwin. 2006. When Movements Matter. Princeton, NJ: Princeton University Press.

Amenta, Edwin, Neal Caren, Elizabeth Chiarello, and Yang Su. 2010. "The Political Consequences of Social Movements." Annual Review of Sociology 36: 287-307.

Andrews, Kenneth T. 2002. "Movement-Countermovement Dynamics and the Emergence of New Institutions: The Case of "White Flight" Schools in Mississippi." Social Forces 80 (3): 911-36.

Angrist, Joshua D., and Jörn-Steffen Pischke. 2008. Mostly Harmless Econometrics: An Empiricist's Companion. Princeton, NJ: Princeton University Press.

Berbuir, Nicole, Marcel Lewandowsky, and Jasmin Siri. 2015. "The AfD and Its Sympathisers: Finally a Right-Wing Populist Movement in Germany?" German Politics 24 (2): 154-78.

Berntzen, Lars Erik, and Manès Weisskircher. 2016. "Anti-Islamic PEGIDA beyond Germany: Explaining Differences in Mobilisation." Journal of Intercultural Studies 37 (6): 556-73.

Blee, Kathleen M., and Kimberly A. Creasap. 2010. "Conservative and Right-Wing Movements." Annual Review of Sociology 36: 269-86.

Borstel, Dierk, and Wilhelm Heitmeyer. 2012. "Menschenfeindliche Mentalitäten, radikalisierte Milieus und Rechtsterrorismus." In Radikale Milieus, eds. Stefan Malthaner and Peter Waldmann, 339-68. Frankfurt am Main, DE: Campus.

Brannen, Samuel J., Christian S. Haig, and Katherine Schmidt. 2020 "The Age of Mass Protests." Center for Strategic and International Studies. March 4. https://www.csis.org/analysis/age-mass-protest.

Breuer, Anita, Todd Landman, and Dorothea Farquhar. 2015.

"Social Media and Protest Mobilization: Evidence from the Tunisian Revolution." Democratization 22 (4): 764-92.

Bursztyn, Leonardo, Davide Cantoni, David Y. Yang, Noam Yuchtman, and Y. Jane Zhang. 2021. "Persistent Political Engagement: Social Interactions and the Dynamics of Protest Movements." American Economic Review: Insights 3 (2): 233-50. Cantoni, Davide, David Y. Yang, Noam Yuchtman, and Y. Jane Zhang. 2019. "Protests as Strategic Games: Experimental
Evidence from Hong Kong's Antiauthoritarian Movement." The Quarterly Journal of Economics 134 (2): 1021-77.

Chermak, Steven, Joshua Freilich, and Michael Suttmoeller. 2013. "The Organizational Dynamics of Far-Right Hate Groups in the United States: Comparing Violent to Nonviolent Organizations." Studies in Conflict \& Terrorism 36 (3): 193-218.

Chong, Dennis. 2014. Collective Action and the Civil Rights Movement. Chicago: University of Chicago Press.

Coate, Stephen, and Michael Conlin. 2004. "A Group RuleUtilitarian Approach to Voter Turnout: Theory and Evidence." American Economic Review 94 (5): 1476-504.

Cress, Daniel M., and David A. Snow. 2000. "The Outcomes of Homeless Mobilization: The Influence of Organization, Disruption, Political Mediation, and Framing." American Journal of Sociology 105 (4): 1063-104.

Danaher, William F. 2010. "Music and Social Movements." Sociology Compass 4 (9): 811-23.

Davis, Gerald F., Doug McAdam, W. Richard Scott, and Mayer N. Zald. 2005. Social Movements and Organization Theory. Cambridge: Cambridge University Press.

Della Porta, Donatella. 2006. Social Movements, Political Violence, and the State: A Comparative Analysis of Italy and Germany. Cambridge: Cambridge University Press.

de Vries, Catherine E., and Sara B. Hobolt. 2020. Political Entrepreneurs: The Rise of Challenger Parties in Europe. Princeton, NJ: Princeton University Press.

Eyerman, Ron. 2002. "Music in Movement: Cultural Politics and Old and New Social Movements." Qualitative Sociology 25 (3): 443-58.

Eyerman, Ron, and Andrew Jamison. 1998. Music and Social Movements: Mobilizing Traditions in the Twentieth Century. Cambridge: Cambridge University Press.

Finkel, Steven E. 1985. "Reciprocal Effects of Participation and Political Efficacy: A Panel Analysis.” American Journal of Political Science 29 (4): 891-913.

Fireman, Bruce, and William A. Gamson. 1977. "Utilitarian Logic in the Resource Mobilization Perspective." In The Dynamics of Social Movements, eds. Mayer Zald and John McCarthy, 8-45. Cambridge, MA: Winthrop.

Flacks, Dick. 1988. "The Sociology Liberation Movement: Some Legacies and Lessons." Critical Sociology 15 (2): 9-18.

Freedman, David A. 2008. "Randomization Does Not Justify Logistic Regression." Statistical Science 23: 237-49.

Glazer, Amihai. 2008. "Voting to Anger and to Please Others." Public Choice 134 (3-4): 247-54.

González, Felipe. 2020. "Collective Action in Networks: Evidence from the Chilean Student Movement." Journal of Public Economics 188: article 104220.

Hager, Anselm, Lukas Hensel, Johannes Hermle, and Christopher Roth. 2019. "Political Activists as Free-Riders: Evidence from a Natural Field Experiment." IZA Discussion Paper 12759.

Hager, Anselm, Lukas Hensel, Johannes Hermle, and Christopher Roth. 2021a. "Does Party Competition Affect Political Activism?" Journal of Politics. 83 (4): 1681-94.

Hager, Anselm, Lukas Hensel, Johannes Hermle, and Christopher Roth. 2021b. "Replication Data for: Group Size and Protest Mobilization across Movements and Countermovements." Harvard Dataverse. Dataset. https:/doi.org/10.7910/DVN/ MUSFYH.

Hager, Anselm, and Krzysztof Krakowski. 2021. "Does State Repression Spark Protests? Evidence from Secret Police Surveillance in Communist Poland." American Political Science Review, 1-16. https://doi.org/10.1017/S0003055421000770.

Hall, Simon. 2011. Peace and Freedom: The Civil Rights and Antiwar Movements in the 1960s. Philadelphia: University of Pennsylvania Press.

Han, Hahrie. 2016. "The Organizational Roots of Political Activism: Field Experiments on Creating a Relational Context." American Political Science Review 110 (2): 296-307.

Huddy, Leonie, Stanley Feldman, and Erin Cassese. 2007. "On the Distinct Political Effects of Anxiety and Anger." In The Affect Effect: Dynamics of Emotion in Political Thinking and Behavior, eds. W. Russell Neuman, George E. Marcus, and Michael MacKuen, 202-30. Chicago: University of Chicago Press.

Huddy, Leonie, and Lilliana Mason. 2008. "Heated Campaign Politics: An Intergroup Conflict Model of Partisan Emotions." 
Paper presented at the Annual Meeting of the American Political Science Association, Boston, MA.

Hutter, Swen. 2014. Protesting Culture and Economics in Western Europe: New Cleavages in Left and Right Politics. Minneapolis: University of Minnesota Press.

Hutter, Swen, Edgar Grande, and Hanspeter Kriesi. 2016. Politicising Europe. Cambridge: Cambridge University Press.

Jennings, M. Kent, and Ellen Ann Andersen. 1996. "Support for Confrontational Tactics among AIDS Activists: A Study of IntraMovement Divisions." American Journal of Political Science 40 (2): 311-34.

Jennings, Will, and Clare Saunders. 2019. "Street Demonstrations and the Media Agenda: An Analysis of the Dynamics of Protest Agenda Setting." Comparative Political Studies 52 (13-14): 2283-313.

Klandermans, Bert. 1984. "Mobilization and Participation: SocialPsychological Expansions of Resource Mobilization Theory." American Sociological Review 49 (5): 583-600.

Klandermans, Bert. 1997. The Social Psychology of Protest. Hoboken, NJ: Blackwell Publishing.

Klandermans, Bert, and Dirk Oegema. 1987. "Potentials, Networks, Motivations, and Barriers: Steps towards Participation in Social Movements." American Sociological Review 52 (4): 519-31.

Klandermans, Bert, and Jacquelien van Stekelenburg. 2013. "Social Movements and the Dynamics of Collective Action." In The Oxford Handbook of Political Psychology, 2nd edition, eds. Leonie Huddy, David O. Sears, and Jack S. Levy, 774-811. Oxford: Oxford University Press.

Kriesi, Hanspeter. 1989. "New Social Movements and the New Class in the Netherlands." American Journal of Sociology 94 (5): 1078-116.

Kriesi, Hanspeter. 1996. "The Organizational Structure of New Social Movements in a Political Context." In Comparative Perspectives on Social Movements: Political Opportunities, Mobilizing Structures, and Cultural Framings, eds. Doug McAdam, John D. McCarthy, and Mayer N. Zald, 152-84. Cambridge: Cambridge University Press.

Kriesi, Hanspeter, Edgar Grande, Swen Hutter, Argyrios Altiparmakis, Endre Borbáth, Simon Bornschier, Björn Bremer et al. 2020. PolDem-National Election Campaign Dataset [computer file]. Version 1. PolDem [distributor].

Lacetera, Nicola, and Mario Macis. 2010. "Social Image Concerns and Prosocial Behavior: Field Evidence from a Nonlinear Incentive Scheme." Journal of Economic Behavior \& Organization 76 (2): 225-37.

Lehrer, Roni, Sebastian Juhl, and Thomas Gschwend. 2019. "The Wisdom of Crowds Design for Sensitive Survey Questions." Electoral Studies 57: 99-109.

Lohmann, Susanne. 1994. "The Dynamics of Informational Cascades: The Monday Demonstrations in Leipzig, East Germany, 1989-91." World Politics 47 (1): 42-101.

Lubell, Mark, and John T. Scholz. 2001. "Cooperation, Reciprocity, and the Collective-Action Heuristic." American Journal of Political Science 45 (1): 160-78.

McAdam, Doug. 1986. "Recruitment to High-Risk Activism: The Case of Freedom Summer." American Journal of Sociology 92 (1): 64-90.

McAdam, Doug, John D. McCarthy, and Mayer N. Zald. 1988. Social Movements. New York: Sage Publications.

McAdam, Doug, and Ronnelle Paulsen. 1993. "Specifying the Relationship between Social Ties and Activism." American Journal of Sociology 99 (3): 640-67.

McAdam, Doug, and Sidney, Tarrow. 2013. "Contentious Politics." In The Wiley-Blackwell Encyclopedia of Social and Political Movements, eds. David Snow, Donatella Della Porta, Bert Klandermans, and Doug McAdam, 19-43. Hoboken, NJ: Blackwell Publishing.

McAllister, Ian, and Donley T. Studlar. 1991. "Bandwagon, Underdog, or Projection? Opinion Polls and Electoral Choice in Britain, 1979-1987." The Journal of Politics 53 (3): 720-41.

McClendon, Gwyneth H. 2014. "Social Esteem and Participation in Contentious Politics: A Field Experiment at an LGBT Pride Rally." American Journal of Political Science 58 (2): 279-90.

McVeigh, Rory, David Cunningham, and Justin Farrell. 2014 "Political Polarization as a Social Movement Outcome: 1960s Klan
Activism and Its Enduring Impact on Political Realignment in Southern Counties, 1960 to 2000." American Sociological Review 79 (6): 1144-71.

Meadowcroft, John, and Elizabeth A. Morrow. 2017. "Violence, SelfWorth, Solidarity and Stigma: How a Dissident, Far-Right Group Solves the Collective Action Problem.” Political Studies 65 (2): 373-90.

Meyer, David S. 2004. "Protest and Political Opportunities." Annual Review of Sociology 30: 125-45.

Meyer, David S., and Suzanne Staggenborg. 1996. "Movements, Countermovements, and the Structure of Political Opportunity." American Journal of Sociology 101 (6): 1628-60.

Morton, Rebecca B., and Kai Ou. 2015. "What Motivates Bandwagon Voting Behavior: Altruism or a Desire to Win?" European Journal of Political Economy 40: 224-41.

Mudde, Cas. 1996. "The War of Words Defining the Extreme Right Party Family.” West European Politics 19 (2): 225-48.

Mudde, Cas. 2007. Populist Radical Right Parties in Europe. Cambridge: Cambridge University Press.

Niedermayer, Oskar, and Jürgen Hofrichter. 2016. "Die Wählerschaft der AfD: Wer ist sie, woher kommt sie und wie weit rechts steht sie?" Zeitschrift für Parlamentsfragen 2: 267-84.

Oliver, Pamela. 1984. “'If You Don't Do it, Nobody Else Will': Active and Token Contributors to Local Collective Action." American Sociological Review 49 (5): 601-10.

Olson, Mancur. 1965. The Logic of Collective Action: Public Goods and the Theory of Groups. Cambridge, MA: Harvard University Press.

Ostrom, Elinor. 2000. "Collective Action and the Evolution of Social Norms." The Journal of Economic Perspectives 14 (3): 137-58.

Polletta, Francesca, and James M. Jasper. 2001. "Collective Identity and Social Movements." Annual Review of Sociology 27: 283-305.

Rucht, Dieter, Peter Hocke, and Thomas Ohlemacher. 1992. Dokumentation und Analyse von Protestereignissen in der Bundesrepublik Deutschland (Prodat) Codebuch. Berlin: Wissenschaftszentrum Berlin.

Rydgren, Jens. 2010. "Radical Right-Wing Populism in Denmark and Sweden: Explaining Party System Change and Stability." SAIS Review of International Affairs 30 (1): 57-71.

Shadmehr, Mehdi. 2021. "Protest Puzzles: Tullock's Paradox, Hong Kong Experiment, and the Strength of Weak States." Quarterly Journal of Political Science 16 (3): 245-64.

Siri, Jasmin. 2018. "The Alternative for Germany after the 2017 Election." German Politics 27 (1): 141-45.

Snow, David A., and Sarah A. Soule. 2010. A Primer on Social Movements. New York: W. W. Norton.

Snow, David A., Louis A. Zurcher Jr., and Sheldon Ekland-Olson. 1980. "Social Networks and Social Movements: A Microstructural Approach to Differential Recruitment." American Sociological Review 55 (5): 787-801.

Tarrow, Sidney. 1996a. "Social Movements in Contentious Politics: A Review Article." American Political Science Review 90 (4): 874-83.

Tarrow, Sidney. 1996b. "States and Opportunities: The Political Structuring of Social Movements." In Comparative Perspectives on Social Movements: Political Opportunities, Mobilizing Structures, and Cultural Framings, eds. Doug McAdam, John D. McCarthy, and Mayer N. Zald, 41-61. Cambridge: Cambridge University Press.

Tarrow, Sidney G. 2011. Power in Movement: Social Movements and Contentious Politics. Cambridge: Cambridge University Press.

Uhlaner, Carole J. 1989. "Relational Goods' and Participation: Incorporating Sociability into a Theory of Rational Action." Public Choice 62 (3): 253-85.

Vann, Burrel, Jr. 2018. "Movement-Countermovement Dynamics and Mobilizing the Electorate." Mobilization: An International Quarterly 23 (3): 285-305.

Vüllers, Johannes, and Sebastian, Hellmeier. 2021. "Does CounterMobilization Contain Right-Wing Populist Movements? Evidence from Germany." European Journal of Political Research. https:// doi.org/10.1111/1475-6765.12439.

Wiltfang, Gregory L., and Doug McAdam. 1991. "The Costs and Risks of Social Activism: A Study of Sanctuary Movement Activism." Social Forces 69 (4): 987-1010. 